\title{
Occupational health Profile and Problems Among Female Workers Processing dried Tobacco leaves in Tobacco industries
}

\author{
B.S. Wali, V.N. Patil and P.D. Raut ${ }^{*}$ \\ Department of Zoology, Shivaji University, Kolhapur, \\ Department of Environmental Science*, \\ Shivaji University, Kolhapur - 416004 (M.S.),India.
}

\begin{abstract}
Work related hazards and stresses are the emerging problems all over the world. These affect worker's health, work efficiency and productivity of any industry. Work place stress has relation with mental, physical and physiological functioning of the workers. In our country most of the females are working in tobacco processing industries. Keeping this fact in the view, study of occupational hazards in tobacco industries in Jaysingpur city of Kolhapur district was carried out. Cardiovascular diseases, illness related with respiratory system, throat dryness, breathing problems and musculo-skeletal disorders are the problems among female tobacco workers exposed to tobacco dust.
\end{abstract}

Keywords: Female tobacco workers, Injuries, Occupational hazards, Workplace.

\section{Introduction}

Occupational health hazards and stresses are prevalent among many occupations. Management of these is a challenge to the workers and their well being organizations. Tobacco industry is an unorganized sector, providing employment to the rural population especially women. It is age old and hazardous industry having its bad impact on human health. Tobacco dust produced during processing of dried tobacco leaves is directly affecting worker's health. Stresses at the work place arise due to work demands, poor support, nightshifts, faulty designed work place and work load. Stress can create psychological injuries like depression, anxiety, emotional distress and sometimes suicide by sufferer. Physiological illness includes cardiovascular diseases, musculo-skeletal disorders (MSD), immune deficiency and gastrointestinal disorders. Environmental stressors like physical, chemical and biological agents can affect the comfort and performance at the workplace. Environmental stressors include noise, extreme heat, inadequate illumination, vibration, dust which make workplace unfavorable for workers. Unguarded machineries, workload, lack of social environment can create stressful conditions. Viral infections, coronary heart diseases, headache, stomach problems are the health problems experienced by workers. Matthews et al. (1987) has reported stressful work conditions and diastolic blood pressure among blue collar factory workers. Healthy work, stress management, productivity and reconstruction of working life were explicated by Karasek and Theorell (1990). Lack of social relation at work, burden, work deadlines, frustration creates psychological health problems.

Workplace stresses emerge when work demand exceeds the working capacity especially during peak seasons. Physical health problems include fatigue, headache, heart palpitations, insomnia, gastrointestinal and skin problems. Behavioral symptoms include increase in sickness days, absenteeism, drop 
in work performance, frustration, mood swings and loneliness etc. Poor socio-economic status and illiteracy make them to accept the work. Low socio economic status is associated with total morbidity and mortality as given by Adler, (1999). Unhygienic workplaces in units are giving respiratory impairments, lack of washrooms, toilets and pure drinking water has made workplace hazardous to their health.

Jaysingpur (District- Kolhapur, Maharashtra) is a suburb where tobacco industry comes under unorganized sector. Female workers working in tobacco industries have migrated from rural areas and border lines of Karnataka. It is one of the old and hazardous occupations, where modern facilities and protective equipments are not used. Labours clean up tobacco with hands using some old household appliances. In tobacco processing units in Jaysingpur city of Kolhapur district, Maharashtra, workplace conditions are extremely adverse. Working conditions show severity of health hazards in these Tobacco Processing Units. Shift work and accidents even make working conditions more hazardous. Anyhow, it is providing employment to rural women but its bad health impacts are neglected. Heavy muscular work is done by females. Lifting and carrying heavy tobacco bales, awkward body postures, twisting of body invite musculoskeletal disorders. Severe muscular pain, spinal cord injuries were reported by the workers. Coughing, cold, gastrointestinal problems are the few health problems.

\section{Materials and Methods}

Study area selected to carry out present investigation was Jaysingpur city of Kolhapur district, Maharashtra, India. Tobacco processing units with higher annual turnover were identified and selected for present study. In each tobacco processing unit 8 to 10 women are working. Fifty four female tobacco workers with age up to 60 years were selected randomly from different tobacco processing units. A standard questionnaire was prepared and information was gathered about their health, marital status, monthly income, disease history etc. Interviews were conducted to interact with female tobacco workers. For assessing physiological parameters standard physiological instruments were used. Sphyngometer was used to measure blood pressure. Radial pulse was used to count pulse rate. Clinical thermometer was used to measure body temperature. Weighing machine and measuring tape was used to record anthropometric characters. The collected data is interpreted by frequency and using one way ANOVA. Besides these observations, photo documentation was carried out during visits to assess working conditions in different seasons.

\section{Results and Discussion}

Results of the present study reveals that age of female tobacco workers ranges in between 17 to 50 years. Table 1 . shows the population analysis of the workers showing married $(61.11 \%)$, widows $(16.66 \%)$ and single $(22.22 \%)$ population. Domestic violence by their alcoholic husband makes them to carry their children along with them. Children accompanying their mother at the workplace have meals in unhygienic workplace conditions are possibly prone to exposure.

Workers of all ages are found working in these

Table 1 Physiological profile of female Tobacco Workers $(n=54$, Mean \pm S.D.)

\begin{tabular}{|c|c|c|c|}
\hline $\begin{array}{c}\text { Sr. } \\
\text { no. }\end{array}$ & $\begin{array}{c}\text { Physiological } \\
\text { parameters }\end{array}$ & $\begin{array}{c}\text { Measured } \\
\text { value (Mean } \pm \\
\text { S.D) }\end{array}$ & $\begin{array}{c}\text { Recommend- } \\
\text { ed value }\end{array}$ \\
\hline 1 & Weight (kg) & $48.68 \pm 10.13$ & 54.4 \\
\hline 2 & Height (cm) & $150 \pm 4.98$ & 164.0 \\
\hline 3 & $\begin{array}{c}\text { Pulse rate } \\
\text { (beta/min.) }\end{array}$ & $75.42 \pm 7.25$ & $70-80$ \\
\hline 4 & $\begin{array}{c}\text { Body tempera- } \\
\left.\text { ture ( }{ }^{\circ} \mathrm{C}\right)\end{array}$ & $37.59 \pm 1.37$ & 37 \\
\hline 5 & $\begin{array}{c}\text { Systolic blood } \\
\text { pressure (mm/ } \\
\text { Hg) }\end{array}$ & $125 \pm 12.95$ & 120 \\
\hline 6 & $\begin{array}{c}\text { Diastolic blood } \\
\text { pressure (mm/ } \\
\mathrm{Hg})\end{array}$ & $72.11 \pm 8.44$ & 80 \\
\hline 7 & PEFR (lit/min) & $281.29 \pm 43.09$ & 350 \\
\hline
\end{tabular}




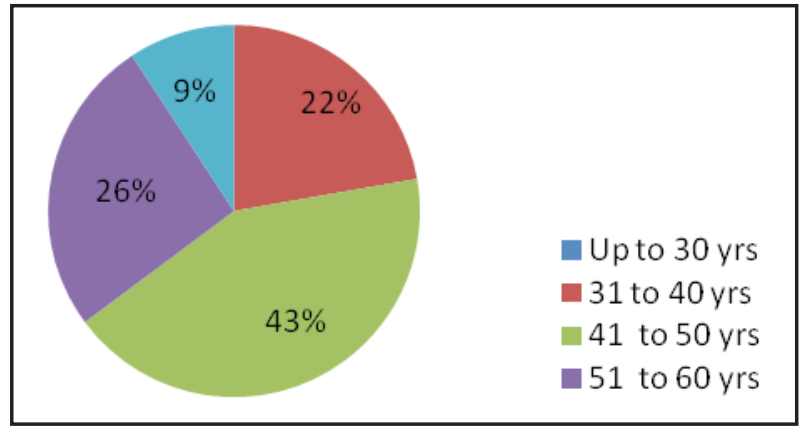

Fig. 1 Percentage of workers according to different age groups.

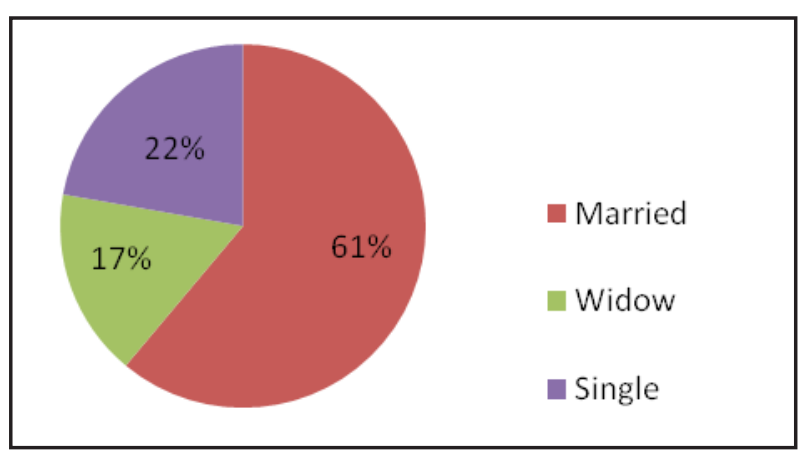

Fig. 2 Percentage of workers according to their marital status.

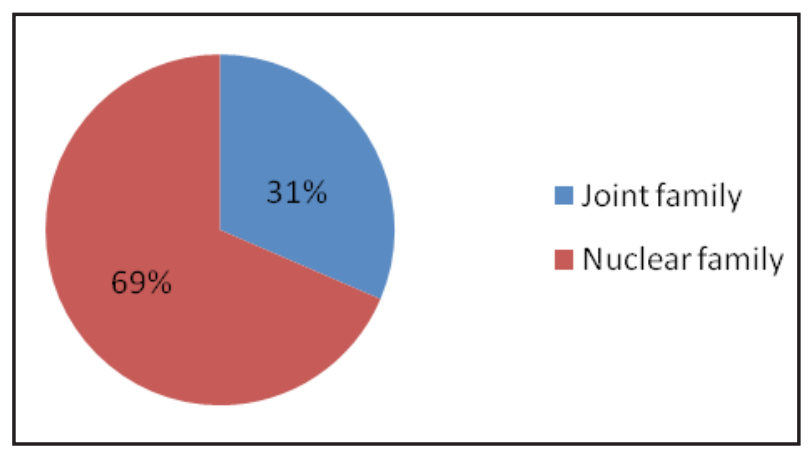

Fig. 3 Percentage distribution of family type of workers.

tobacco processing units. Average weight of the subjects was $48.68 \mathrm{~kg} \pm 10.13$., which was less than normal weight. This weight reduction is mainly because of malnutrition and heavy muscular work at the workplace. Weight reduction affects workers physical fitness test performances. Average height of the subjects was $150 \mathrm{~cm} \pm 4.98$. This was also found less than normal value. Mean pulse rate was 75.42 per minute \pm 7.25 pulse rate shows normal range. Body temperature recorded was in normal range i. e. $37.59^{\circ} \mathrm{C}$ \pm 1.37 . Average systolic blood pressure was found under normal range i.e. $125 \pm 12.95$ $\mathrm{mm} / \mathrm{hg}$. For diastolic blood pressure, average values were $72.11 \mathrm{~mm} / \mathrm{Hg} \pm 8.44$. These normal values indicate good cardiovascular system because of heavy muscular work done by female workers. Peak Expiratory Flow Rate (PEFR) significantly reduced and its average is $281.29 \mathrm{lit} / \mathrm{min} \pm$ 43.09. Decrease in PEFR clearly indicates occupational exposure to respirable tobacco dust.

\section{Occupational injuries to female tobacco workers}

Occupational injuries are shown in Table 3. Workers suffer from breathing problems because of exposure to tobacco dust. Musculoskeletal disorders are common among them. Skin allergies were noticed in recent times due to touching raw tobacco without using any protective gloves. Lots of dense tobacco dust and inadequate illumination cause eye irritation and watering in eyes. Accidents and injuries were found to be noticed among workers. Climbing on height for feeding the machine up to 25 to $30 \mathrm{ft}$ and pouring tobacco in to machine is risky job. Gangopadhyay and Sen, (1997) reported an accident in some industries without processes in West Bengal an ergonomic study. Noise produced from machines and vibration makes workplace more hazardous. Prolonged working in awkward body postures creates musculo-skeletal disorders (MSD). Snook, (1983) has studied that MSD are causes of illness of health and partial disability. Fatigue and sprain in body parts are experienced by the female tobacco workers. Lifting and carrying heavy tobacco bales causes sprain in neck and spinal cord. During peak seasons and tight work deadlines make them to work in most stressful conditions.

Headache, vomiting, fainting and acidity are common health problems faced by the workers. 
Table 2. Types of injuries experienced by female tobacco workers $(n=54)$.

\begin{tabular}{|c|l|c|c|}
\hline \multirow{2}{*}{ S. No. } & \multirow{2}{*}{ Types of injury } & \multicolumn{2}{|c|}{ Occurrence of injury } \\
\cline { 3 - 4 } & & Yes & No \\
\hline 1 & Skin allergies & 12.00 & $42(77.7)$ \\
\hline 2 & Fatigue & 42.00 & $12(22.2)$ \\
\hline 3 & Sprain in body & 48.00 & $6(11.11)$ \\
\hline 4 & Swelling of body & 27.00 & $27(50.0)$ \\
\hline 5 & Minor accidents & 8.00 & $46(85.18)$ \\
\hline 6 & Boils in arms & 19.00 & $35(64.81)$ \\
\hline 7 & Cuts and wounds & 15.00 & $39(72.22)$ \\
\hline 8 & Eye irritation and watering & 45.00 & $9(16.66)$ \\
\hline
\end{tabular}

The values in parenthesis indicate percentage.

Table 3. Prevalence of health problems among female tobacco workers $(n=54)$.

\begin{tabular}{|c|l|c|c|}
\hline \multirow{2}{*}{$\begin{array}{c}\text { Sr. } \\
\text { No. }\end{array}$} & \multirow{2}{*}{ Type of illness } & \multicolumn{2}{|c|}{$\begin{array}{c}\text { No. of workers with } \\
\text { illness }\end{array}$} \\
\cline { 3 - 4 } & & Yes & No \\
\hline 1 & Weakness & 35.00 & $19(35.18)$ \\
\hline 2 & Fatigue & 42.00 & $12(22.22)$ \\
\hline 3 & Headache & 34.00 & $10(37.03)$ \\
\hline 4 & Vomiting & 10.00 & $44(81.48)$ \\
\hline 5 & Fainting & 12.00 & $42(77.7)$ \\
\hline 6 & Asthma & 8.00 & $46(85.18)$ \\
\hline 7 & Chest tightness & 25.00 & $29(53.70)$ \\
\hline 8 & Breathing problem & 27.00 & $25(50.00)$ \\
\hline 9 & Nasal and throat dryness & 30.00 & $24(44.44)$ \\
\hline
\end{tabular}

The values in parenthesis indicate percentage

All above factors can create physical and mental stress for the workers (Akerstedt and Gillberg, 1981). Respirable tobacco dust creates respiratory impairments. Handling of raw tobacco results in rashes and allergies causing itching. Twisting of body parts and carrying heavy loads wrong way leads to swelling of body parts and numbness in arms.
Women worker reported body fatigue and sprains which results due to heavy muscular work. Working in awkward body postures, lifting and carrying heavy loads does not maintain required body postures. Continuous standing, bending and sitting in awkward postures and twisting of body parts can create work related musculoskeletal disorders. Puncture of body parts after hitting with pointed machinery edges are noticed among the female tobacco workers. During summer season heat stroke and dehydration may create severe health problems. Lack of pure drinking water and absence of toilets may invite infections. Headache, breathlessness, phlegm, sore throat, chest tightness and coughing are major health problems which occurred due to unhealthy workplace conditions. All jobs at the workplace are manually performed by female workers starting from removing semi dried tobacco leaves from the bales until storing processed tobacco in the storage section. Heavy muscular activity and stresses at workplace makes workers to lose their strength and prone to occupational stresses and hazards.

\section{Occupational health profile and problems among female workers}

During stressful conditions workers undergo loss of appetite or over eating, smoking, alcohol abuse, sleeping disorders, lack of mind control, emotions, violence and aggression (Randolfi, 1997). Chattarjee and Mirai, (1994) have studied occupational health of self employed women workers. Dinesh and Mohan, (1990) studied on the hazardous working conditions of Rural women. Tobacco dust released during processing gets accumulated into indoor workplace environment. Absence of dust controlling equipments will make workplace severely hazardous. Dust concentration is very dense and makes female workers invisible to each other. Chest tightness, coughing, and phlegm are the frequently occurring health problems. Women continuously exposed to tobacco dust show adverse reproductive outcomes (Gupta et al., 1992). 
All injuries and health problems found among female tobacco workers are occupation related.

Occupational stresses and domestic violence by their alcoholic husbands will affect their health adversely. Psychological and behavioral changes are also noticed. Continuous standing for prolonged period, manual collection of processed tobacco causes pain in hands and legs. Sprain in shoulders and spinal cord are the common health problems. Dusty environment causes headache, vomiting and sometimes fainting. Cardiovascular diseases, respiratory disorders and reproductive disorders also prevail among the workers. Therefore, present study was carried out to asses work injuries and awareness in workers about physical welfare. Female tobacco workers are from poor socio-economic status and living below poverty line. They are illiterate; they don't have alternative work rather than working in these unorganized tobacco processing units.

From the present study it is noticed that work related injuries are frequently high among female tobacco workers processing dried tobacco leaves. This industry is neglected by labour union and Government in terms of health policies and facilities. They are far away from modern facilities. Workplace is severely hazardous and women lack protective equipments. For heavy muscular work women require physical stability. Development of disorders is due to occupational hazards and stresses. Tobacco dusts, inadequate illumination, excess of temperature, improper ventilation also contribute for the same. Lack of pure drinking water facility and lack of toilets invite many health consequences. Faulty workplace design, awkward body postures, lifting and carrying heavy loads cause musculoskeletal disorders. Ergonomic study of the activities and well being of workers through proper implementation of hygienic practices is necessary as labour is unorganized in this sector.

\section{Acknowledgements}

Authors express deep sense of gratitude towards Department of Zoology and Division of Physiology, Shivaji University, Kolhapur for providing equipments required for health assessment of the workers. Authors are also thankful to female tobacco workers and industry owners for their co-operation during the study. Authors are thankful to Dr. Vijay Sawant for his guidance in clinical investigations.

\section{References}

Adler, N. E. and Ostrove, J. M. (1999) Socioeconomic status and health. Ann Newyork Acad Sc., 896, Wiley pub. 3-15.

Akerstedt, T. and Gillberg, M. (1981) Sleep disturbances and shift work. In Reinberg A, Vieux, N. Andlauer, P. (edt): Night and Shift Work: Biological and Social Aspects. Oxford, Pergamon Press, 127.

Chatterjee, and Mirai (1994) Occupational Health of Self-Employed Women-Some Experiences, FRCH Newsletter 8, 6-9.

Dinesh and Mohan (1990) The Hazardous Working Conditions of Rural Women. Manushi. J Women Soc 59, Manushi, New Dehli, 25-28.

Gangopadhyay, S. and Sen, R. N. (1997) An ergonomic study on reportable accidents in some industries without processes in West Bengal. Ind $J$ Indus Med. 43, 7-9.

Gupta, P.C., Hamner, J. K., Murti, P. R. (1992) Control of tobacco related cancers and other diseases, Proceeding of an International Symposium, January 1990, TIFR, Bombay, Oxford University Press, 15-19.

Karasek, R. A. and Theorell, T. (1990) Healthy work: stress, productivity, and the reconstruction of working life, Basic Books pub., New York.

Matthews, K. Cottigen, E. N., Talbott, E. Kuller, L. H. Siegl, J. M. (1987) Stressful work conditions and diastolic blood pressure among blue collar factory workers. Am J Epidemiol. 16, 280-91.

Randolfi (1997) Developing a stress management and relaxation center for the worksite, Report of Agricultural Workers Health Project (AWHP) by California Rural Legal Assistance (CRLA) Worksite Health 3, 40-44.

Snook, S. H. (1983) Back and other musculo-skeletal disorders in Occupational Health. Ed. B. S. Levy and D. H. Wegman, Little Brown pub. Boston, 345-70. 